\title{
Front Matter: Volume 8109
}

, "Front Matter: Volume 8109," Proc. SPIE 8109, Solar Hydrogen and Nanotechnology VI, 810901 (23 September 2011); doi: 10.1117/12.906483

SDIE Event: SPIE Solar Energy + Technology, 2011, San Diego, California, United SPIE. States 


\section{PROCEEDINGS OF SPIE}

\section{Solar Hydrogen and Nanotechnology VI}

\section{Yasuhiro Tachibana}

Editor

23-25 August 2011

San Diego, California, United States

Sponsored by

SPIE

\section{Cosponsored by}

Platform Technologies Research Institute, RMIT University (Australia)

Published by

SPIE 
The papers included in this volume were part of the technical conference cited on the cover and title page. Papers were selected and subject to review by the editors and conference program committee. Some conference presentations may not be available for publication. The papers published in these proceedings reflect the work and thoughts of the authors and are published herein as submitted. The publisher is not responsible for the validity of the information or for any outcomes resulting from reliance thereon.

Please use the following format to cite material from this book:

Author(s), "Title of Paper," in Solar Hydrogen and Nanotechnology VI, edited by

Yasuhiro Tachibana, Proceedings of SPIE Vol. 8109 (SPIE, Bellingham, WA, 2011) Article CID Number.

ISSN 0277-786X

ISBN 9780819487193

Published by

SPIE

P.O. Box 10, Bellingham, Washington 98227-0010 USA

Telephone +1 3606763290 (Pacific Time) · Fax +1 3606471445

SPIE.org

Copyright () 2011, Society of Photo-Optical Instrumentation Engineers

Copying of material in this book for internal or personal use, or for the internal or personal use of specific clients, beyond the fair use provisions granted by the U.S. Copyright Law is authorized by SPIE subject to payment of copying fees. The Transactional Reporting Service base fee for this volume is $\$ 18.00$ per article (or portion thereof), which should be paid directly to the Copyright Clearance Center (CCC), 222 Rosewood Drive, Danvers, MA 01923. Payment may also be made electronically through CCC Online at copyright.com. Other copying for republication, resale, advertising or promotion, or any form of systematic or multiple reproduction of any material in this book is prohibited except with permission in writing from the publisher. The CCC fee code is 0277-786X/11/ \$18.00.

Printed in the United States of America.

Publication of record for individual papers is online in the SPIE Digital Library.

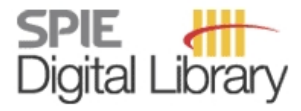

SPIEDigitalLibrary.org

Paper Numbering: Proceedings of SPIE follow an e-First publication model, with papers published first online and then in print and on CD-ROM. Papers are published as they are submitted and meet publication criteria. A unique, consistent, permanent citation identifier (CID) number is assigned to each article at the time of the first publication. Utilization of CIDs allows articles to be fully citable as soon as they are published online, and connects the same identifier to all online, print, and electronic versions of the publication. SPIE uses a six-digit CID article numbering system in which:

- The first four digits correspond to the SPIE volume number.

- The last two digits indicate publication order within the volume using a Base 36 numbering system employing both numerals and letters. These two-number sets start with 00, 01, 02, 03, 04 , $05,06,07,08,09,0 A, 0 B \ldots$. OZ, followed by 10-1Z, 20-2Z, etc.

The CID number appears on each page of the manuscript. The complete citation is used on the first page, and an abbreviated version on subsequent pages. Numbers in the index correspond to the last two digits of the six-digit CID number. 


\section{Contents}

vii Conference Committee

ix Solar Energy Grid Integration Systems (SEGIS): adding functionality while maintaining reliability and economics (Plenary Paper) [81 1202]

W. Bower, Sandia National Labs. (United States)

\section{SESSION 1 CHARGE GENERATION AND TRANSFER MECHANISMS FOR SOLAR WATER SPLITTING}

810903 Interfacial charge transfer dynamics in $\mathrm{TiO}_{2}$-sensitizer-RU44 $\mathrm{POM}$ photocatalytic systems for water oxidation (Invited Paper) [8109-02]

Z. Huang, Y. V. Geletii, D. Wu, C. L. Anfuso, D. G. Musaev, C. L. Hill, T. Lian, Emory Univ. (United States)

810904 Transient absorption study on photogenerated carrier dynamics in visible light responsive photocatalysts GaN:ZnO [8109-03]

A. Furube, National Institute of Advanced Industrial Science and Technology (Japan);

K. Maeda, The Univ. of Tokyo (Japan) and Japan Science and Technology Agency (Japan);

K. Domen, The Univ. of Tokyo (Japan)

\section{SESSION 2 MODELING AND CHARACTERIZATION OF SEMICONDUCTORS}

810907 First principle calculation of stability and effects of doping on sulfur-doped $\mathrm{TiO}_{2}$ [8109-06]

S. Arab, R. Lake, Univ. of California, Riverside (United States)

810908 Theoretical study of the origin of the large difference in the visible absorption spectra of organic dyes containing a thienylmethine unit and differing by the methine unit position (Invited Paper) [8109-07]

S. Manzhos, M. Komatsu, J. Nakazaki, H. Segawa, K. Yamashita, The Univ. of Tokyo (Japan)

\section{SESSION $3 \quad$ NEW DESIGN CONCEPTS FOR SOLAR WATER SPLITTING I}

8109 OA Structural and mechanistic studies of tunable, stable, fast multi-cobalt water oxidation catalysts (Keynote Paper) [8109-09]

G. Zhu, H. Lv, J. W. Vickers, Y. V. Geletii, Z. Luo, J. Song, Z. Huang, D. G. Musaev, C. L. Hill, Emory Univ. (United States)

8109 OB A two-step photoexcitation system for photocatalytic water splitting into hydrogen and oxygen under visible light irradiation (Invited Paper) [8109-10]

R. Abe, Hokkaido Univ. (Japan) 


\section{SESSION 4 NEW DESIGN CONCEPTS FOR SOLAR WATER SPLITTING II}

8109 OC Polyoxometalate-based solar cells for water splitting (Invited Paper) [8109-13]

L. Cronin, P. I. Molina, H. N. Miras, Univ. of Glasgow (United Kingdom)

SESSION $5 \quad$ ARTIFICIAL PHOTOSYNTHESIS I

$8109 \mathrm{OH} \quad$ Binding sites of water molecules on GaN (100) surface: DFT calculations [8109-36]

D. Liu, McGill Univ. (Canada); Y. Zhu, NanoAcademic Technologies Inc. (Canada); H. Guo, McGill Univ. (Canada); H. Abou-Rachid, M. Jaidann, Defence Research and Development Canada, Valcartier (Canada); Z. Mi, McGill Univ. (Canada)

SESSION $6 \quad$ ARTIFICIAL PHOTOSYNTHESIS II

8109 OK Hydrogen photo-production from ethanol on $\mathrm{TiO}_{2}$ : a surface science and catalysis study (Invited Paper) [8109-19]

A. M. Nadeem, The Univ. of Auckland (New Zealand); J. M. R. Muir, Univ. of Aberdeen (United Kingdom); G. W. N. Waterhouse, The Univ. of Auckland (New Zealand); H. Idriss, Univ. of Aberdeen (United Kingdom) and SABIC Technology and Innovation (Saudi Arabia)

\section{SESSION 7 ELECTRON TRANSFER DYNAMICS AT SEMICONDUCTOR INTERFACE}

8109 OM Ultrafast charge carrier dynamics and photoelectrochemical properties of ZnO nanowires decorated with Au nanoparticles (Keynote Paper) [8109-21]

J. K. Cooper, Y. Ling, Y. Li, J. Z. Zhang, Univ. of California, Santa Cruz (United States)

8109 ON Photo-induced electron transfer reactions at semiconductor quantum dot interfaces [8109-22]

A. Veamatahau, J. Bo, S. Makuta, K. C. Yaw, RMIT Univ. (Australia); M. Kanehara, T. Teranishi, Univ. of Tsukuba (Japan); Y. Tachibana, RMIT Univ. (Australia), Osaka Univ. (Japan), and Japan Science and Technology Agency (Japan)

810900 Primary photocatalytic reactions in $\mathrm{TiO}_{2}$ nanoparticles studied by time-resolved laser spectroscopy (Invited Paper) [8109-23]

R. Katoh, Nihon Univ. (Japan) and National Institute of Advanced Industrial Science and Technology (Japan); Y. Tamaki, A. Furube, National Institute of Advanced Industrial Science and Technology (Japan)

\section{SESSION 8 STRUCTURE CONTROL FOR SOLAR HYDROGEN}

$81090 Q \quad$ Bio-inspired co-catalysts bonded to a silicon photocathode for solar hydrogen evolution (Invited Paper) [8109-25]

Y. Hou, Technical Univ. of Denmark (Denmark); B. L. Abrams, Haldor Topsøe A/S (Denmark); P. C. K. Vesborg, M. E. Bjørketun, Technical Univ. of Denmark (Denmark); K. Herbst, Haldor Topsøe A/S (Denmark); L. Bech, B. Seger, T. Pedersen, O. Hansen, J. Rossmeisl, S. Dahl, Technical Univ. of Denmark (Denmark); J. K. Nørskov, Technical Univ. of Denmark (Denmark) and Stanford Univ. (United States); I. Chorkendorff, Technical Univ. of Denmark (Denmark) 
8109 OR New layered semiconductors for efficient photoelectrochemical hydrogen and oxygen generation (Invited Paper) [8109-26]

X. Zong, A. Mukherji, G. Q. Lu, L. Wang, The Univ. of Queensland (Australia)

\section{SESSION 9 NEW NANOMATERIAL DESIGN}

8109 OT One-dimensional plasmonic nano-photocatalysts: synthesis, characterization and photocatalytic activity [8109-28]

S. E. Hunyadi Murph, Savannah River National Lab. (United States)

8109 OU Efficient high surface area vertically aligned metal oxide nanostructures for dye-sensitized photoanodes by pulsed laser deposition [8109-29]

R. Ghosh, M. K. Brennaman, J. J. Concepcion, K. Hanson, A. S. Kumbhar, T. J. Meyer,

R. Lopez, The Univ. of North Carolina at Chapel Hill (United States)

8109 0W Synthesis and characterization of titanium doped hematite for photoelectrochemical water splitting [8109-31]

H. Tang, National Renewable Energy Lab. (United States) and Univ. of Denver (United States); M. Matin, Univ. of Denver (United States); H. Wang, M. Al-Jassim, J. Turner, Y. Yan, National Renewable Energy Lab. (United States)

8109 OY Nanostructured phosphides as photoelectrode materials for artificial photosynthesis [8109-33]

W. Wen, S. M. Collins, S. Maldonado, Univ. of Michigan (United States)

Author Index 
Downloaded From: https://www.spiedigitallibrary.org/conference-proceedings-of-spie on 26 Apr 2023

Terms of Use: https://www.spiedigitallibrary.org/terms-of-use 


\title{
Conference Committee
}

\author{
Symposium Chair
}

Martha Symko-Davies, National Renewable Energy Laboratory (United States)

Conference Chair

Yasuhiro Tachibana, RMIT University (Australia)

Program Committee

Hironori Arakawa, Tokyo University of Science (Japan)

Jan Augustynski, University of Warsaw (Poland)

Maria L. Ghirardi, National Renewable Energy Laboratory (United States)

Michael Grätzel, Ecole Polytechnique Fédérale de Lausanne (Switzerland)

Jinghua Guo, Lawrence Berkeley National Laboratory (United States)

Hicham Idriss, University of Aberdeen (United Kingdom) and Robert

Gordon University (United Kingdom)

Akihiko Kudo, Tokyo University of Science (Japan)

Claude Levy-Clement, Centre National de la Recherche Scientifique (France)

Frank E. Osterloh, University of California, Davis (United States)

Ian C. Plumb, Commonwealth Scientific and Industrial Research Organisation (Australia)

John A. Turner, National Renewable Energy Laboratory (United States)

Lionel Vayssieres, National Institute for Materials Science (Japan)

T. Nejat Veziroglu, University of Miami (United States)

Heli Wang, National Renewable Energy Laboratory (United States)

Gunnar Westin, Uppsala University (Sweden)

Upul Wijayantha, Loughborough University (United Kingdom)

Jin Zhong Zhang, University of California, Santa Cruz (United States)

Session Chairs

1 Charge Generation and Transfer Mechanisms for Solar Water Splitting Yasuhiro Tachibana, RMIT University (Australia)

2 Modeling and Characterization of Semiconductors

Lin X. Chen, Argonne National Laboratory (United States) 
3 New Design Concepts for Solar Water Splitting I

Lionel Vayssieres, National Institute for Materials Science (Japan)

4 New Design Concepts for Solar Water Splitting II

Frank E. Osterloh, University of California, Davis (United States)

5 Artificial Photosynthesis I

Ryuzi Katoh, National Institute of Advanced Industrial Science and Technology (Japan)

6 Artificial Photosynthesis II

Jin Zhong Zhang, University of California, Santa Cruz (United States)

$7 \quad$ Electron Transfer Dynamics at Semiconductor Interface Hicham Idriss, University of Aberdeen (United Kingdom)

8 Structure Control for Solar Hydrogen

Heli Wang, National Renewable Energy Laboratory (United States)

9 New Nanomaterial Design

Gunnar Westin, Uppsala University (Sweden)

10 Nanomaterials and Photoelectrochemistry

Yasuhiro Tachibana, RMIT University (Australia) 
Plenary Paper

\title{
Solar Energy Grid Integration Systems (SEGIS) Adding functionality while maintaining reliability and economics
}

\author{
Ward Bower \\ Sandia National Laboratories, Energy Surety Engineering and Analysis, MS0734, Albuquerque, NM 87185-0734
}

\begin{abstract}
An overview of the activities and progress made during the US DOE Solar Energy Grid Integration Systems (SEGIS) solicitation, while maintaining reliability and economics is provided. The SEGIS R\&D opened pathways for interconnecting PV systems to intelligent utility grids and micro-grids of the future. In addition to new capabilities are "value added" features. The new hardware designs resulted in smaller, less material-intensive products that are being viewed by utilities as enabling dispatchable generation and not just unpredictable negative loads. The technical solutions enable "advanced integrated system" concepts and "smart grid" processes to move forward in a faster and focused manner. The advanced integrated inverters/controllers can now incorporate energy management functionality, intelligent electrical grid support features and a multiplicity of communication technologies. Portals for energy flow and two-way communications have been implemented. SEGIS hardware was developed for the utility grid of today, which was designed for one-way power flow, for intermediate grid scenarios, AND for the grid of tomorrow, which will seamlessly accommodate managed two-way power flows as required by large-scale deployment of solar and other distributed generation. The SEGIS hardware and control developed for today meets existing standards and codes AND provides for future connections to a "smart grid" mode that enables utility control and optimized performance.
\end{abstract}

Keywords: SEGIS, inverter, PV systems, smart grid, interconnect, VAr support, communications, energy management.

\section{INTRODUCTION}

The SEGIS Program has progressed from the "Conceptual Design and Market Analysis" through "Prototype Development" and is now completing the "Toward Commercialization" stage. Prototypes spanned system sizes from microinverters $(200 \mathrm{~W})$ through modular/expandable commercial sizes of $100 \mathrm{~kW}$. This SEGIS work focused on gridintegrated systems, but stand-alone energy management controls also enable implementation of micro-grid functionality.

Workshops were organized by Sandia National Laboratories to establish an industry consensus for priorities for the SEGIS solicitation. The Department of Energy Renewable System Interconnection (RSI) study was also used for background. [1,2,3,4] The SEGIS program was a very aggressive and proactive program launched in 2007. It was supported and funded by the U.S. Department of Energy Solar Energy Technologies Program (SETP) through Sandia National Laboratories. It focused on development of advanced and integrated PV balance-of-system (BOS) technologies that enable increasing the penetration of PV into the utility grid while maintaining or improving the power quality and the reliability of the utility grid. The R\&D was, by necessity, a collaborative effort of versatile teams that were selected through a competitive bid process (SEGIS Solicitation) conducted by Sandia National Laboratories. The teams consisted of an inverter manufacturer leading and collaborating with utility, energy management, energy storage and communication expert partners.

\section{THE SEGIS VISION AND INNOVATION}

Highly integrated, innovative, advanced inverters, controllers and related balance-of-system (BOS) hardware and algorithm methodologies for residential and commercial solar energy applications were goals of the SEGIS program. Advanced integrated inverters/controllers incorporated energy management, intelligent electrical grid-related connection, system safety, and a multiplicity of communication technologies. The work focused mainly on grid-integrated features with advanced stand-alone energy management controls to enable full micro-grid functionality included. Portals for energy flow and two-way communications for PV system interactive operations with evolving, smarter metering infrastructures and controls were developed.

wibower@sandia.gov ; Phone505-844-5206; fax 505-844-7786

Reliability of Photovoltaic Cells, Modules, Components, and Systems IV, edited by Neelkanth G. Dhere, Proc. of SPIE Vol. 8112, 811202 - (c) 2011 SPIE · CCC code: 0277-786X/11/\$18 · doi: 10.1117/12.915598 


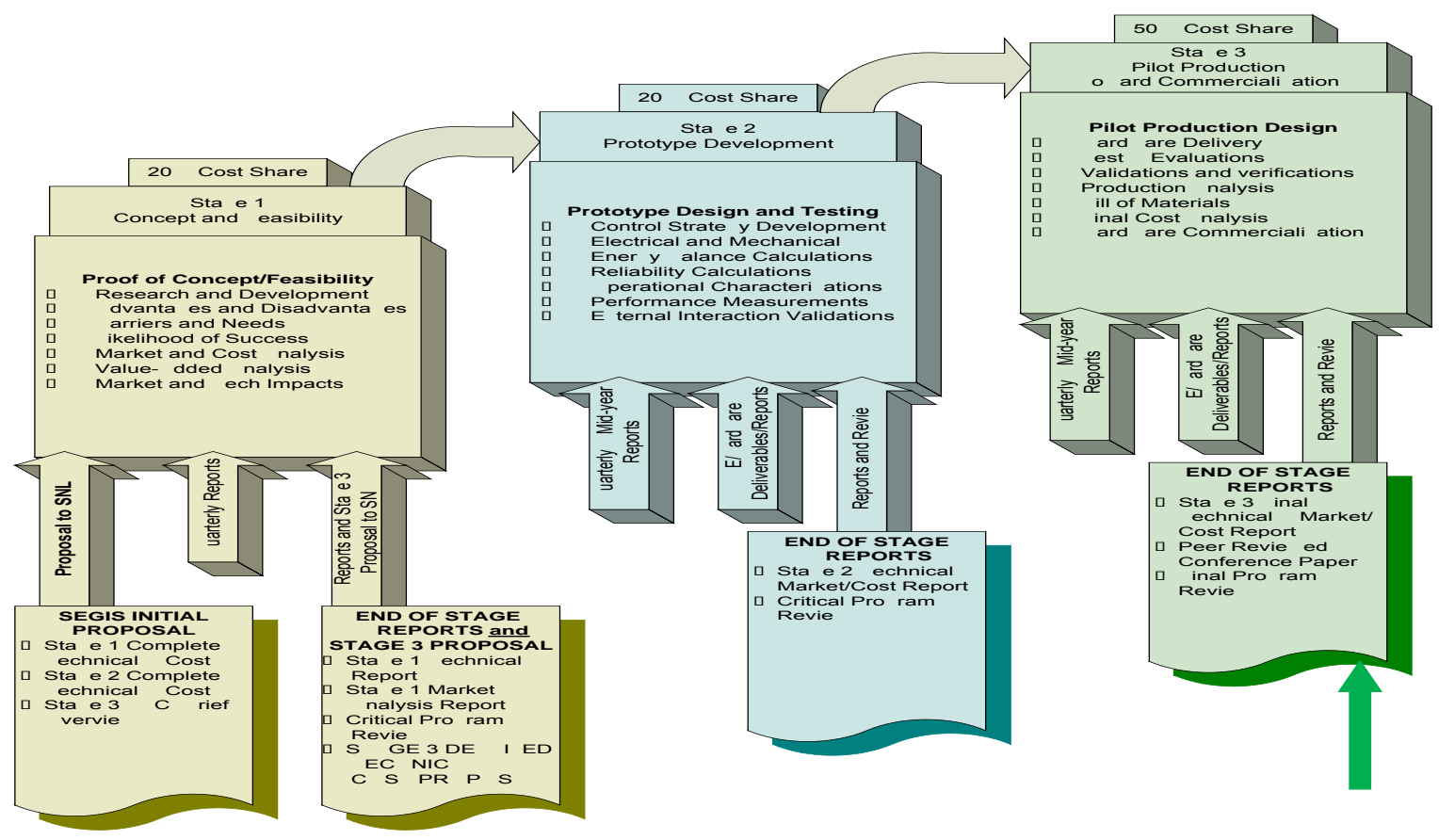

i ure 1. SEGIS timetable sho $n$ ith pro ect status no nearin the end of Sta e 3

SEGIS hardware had to be developed for the utility grid of today, which was designed for one-way power flow, for intermediate grid scenarios, and for the grid of tomorrow, which will accommodate two-way power flows as required by wide-scale deployment of solar and other distributed resources. [1,2] The SEGIS hardware and control developments are necessary to meet existing standards and codes and provide the means for operation and transitions to a smart grid mode to enable utility control, real-time monitoring for optimizing performance and the near-term intelligent grid functionalities.[2,4]

Table 1. List of advanced SEGIS capabilities

- Advanced PV Systems Vertical Integration

- Distributed PV Systems Development

- General Control (Safety, Smart Connect, etc.)

- Energy Storage/Energy Management

- System Level Analysis and Demonstrations

- Basic and Custom Communications

- Utility Command and Data Handling
- VAR Control

- Power Factor Control

- Low Voltage Ride Through

- Ramp Rate Control for Power \& VARs

- Power Curtailment Control

- Basic Microgrid Functionalities

- Codes and Standards Implementations

Several leap-frog and state-of-the-art component and system advances for weight reduction and reliability have been pursued through SEGIS. The roles of inverters, controllers and energy storage have been advanced for better integration into PV systems that are optimized for performance, safety and economics, and that are not disruptive to the utility operations or infrastructures in high penetration scenarios. Figure 1 shows the stages and timetable for the aggressive SEGIS program. Stage 1 was a 9-month effort. Stage 2 prototyping was a 1-year effort completed in June 2010. Stage 3, “Toward Commercialization”, is a 1-year effort begun in August 2010 with completion scheduled for October 2011.

SEGIS developments addressed a multiplicity and the complexity of communications methodologies. Universal concepts included utility-controlled functionality along with many other high-impact functionalities needed for highpenetration PV applications and for economic advantages for both the utilities and owners of PV systems. Those advanced functionalities and capabilities are listed in Table 1. 
Communications is a critical element for moving into and integrating with the grid of the future. Figure 2 shows the mix and number of communications technologies studied by SEGIS contractors. The applications of communications technologies have been advanced and implemented in the SEGIS developments. All contractors and subcontractors studied more than one type of communications to account for varying needs for speed of response, reliability of signals, availability of the technology, and safety resulting from default modes.

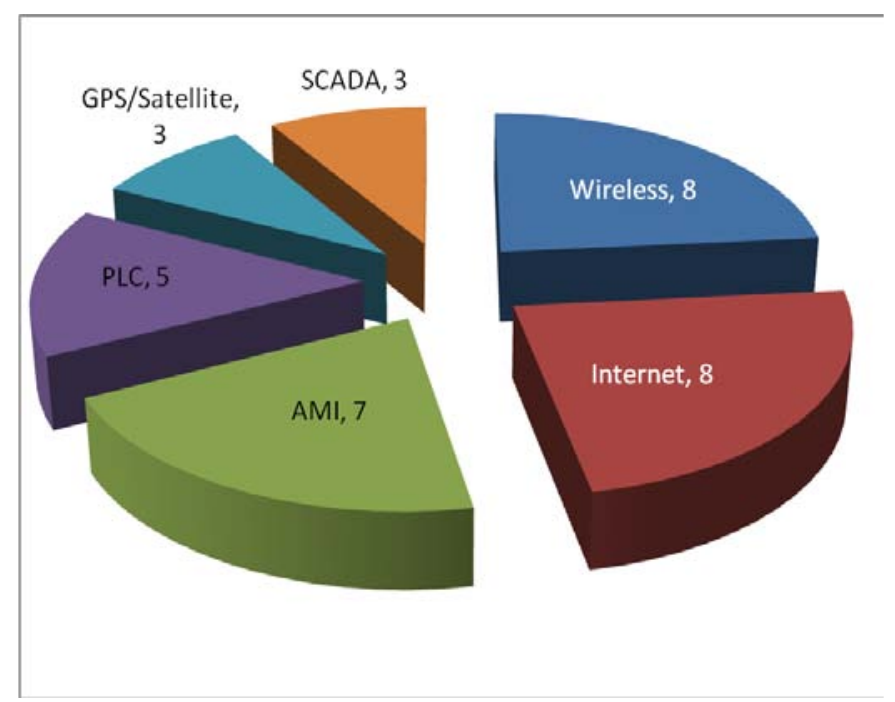

i ure 2. Communications methodologies studied in SEGIS
Promising new solutions for electronic and electrical components, advanced innovative inverter/controller topologies and designs have been integrated into systems. Economical energy management systems and innovative energy storage with advanced control algorithms are now available. Intentional islanding control methods and innovative maximum-power-point tracking suited for all PV technologies were developed.

Other examples of new functionality include ramp rate control that provides a buffer for intermittency of PV power caused by cloud movement over the PV array. Ramp rate control and curtailment commands result in a gradual reversal in output from the PV system that gives conventional utility controls time to react. These functions will be used when high penetration of PV results in voltage rises and falls of the voltage on utility grids with higher impedance.

The new SEGIS inverter/controllers are suited to be operated in micro-grids where the inverter must act as a voltage source and a current source. The transition between the two modes must be fast and smooth in order to not damage sensitive loads and to maintain a supply of power to critical loads. A worse case for the dc side during this transition is when the battery is discharging and then immediately charging once the utility returns. Figure 3 shows the waveforms of a battery charging reversal with a SEGIS inverter when transitioning from utility-interactive to stand-alone operation.

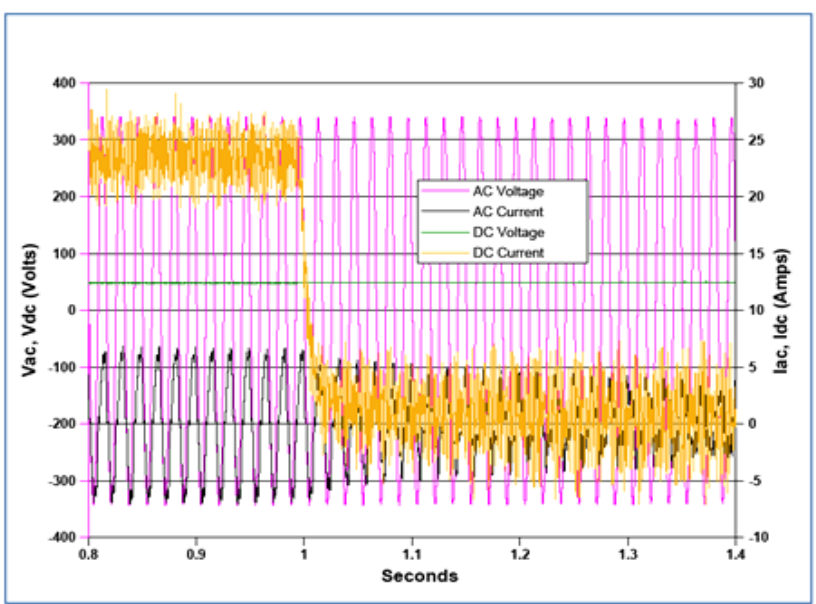

i ure 3 ransition from battery dischar in to battery char in as system chan es from -I to S- operation

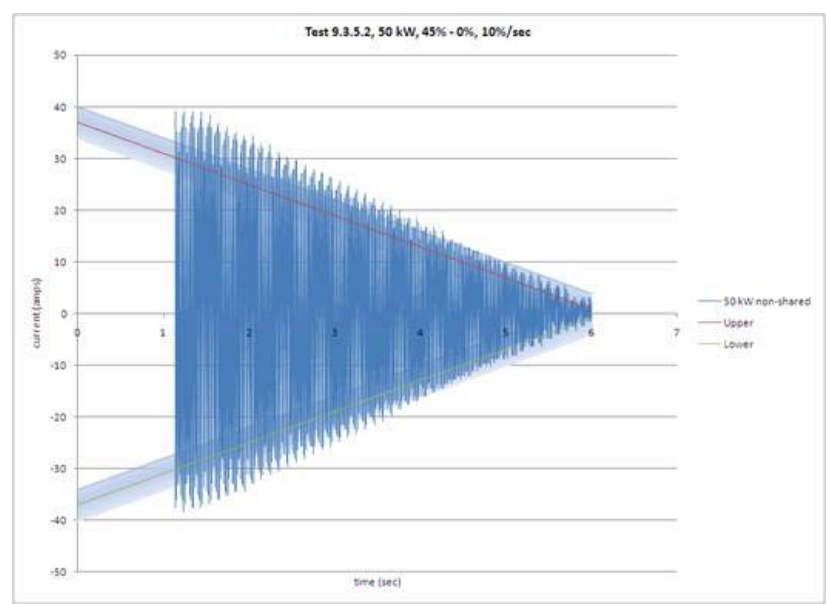

i ure 4 Illustration of a commanded ramp that can help stabili e a rid ith a hi h-penetration of PV 


\section{THE SEGIS DEVELOPMENTS}

The number of, and power ratings of new grid-connected photovoltaic systems are skyrocketing in the United States and in many countries around the world. However, to date, many of the installed systems are "dumb" in that they are designed to simply provide power to the utility grid when the sun shines irrespective of conditions on the grid or needs by the loads. Today there is an increase of remote data monitoring of the systems, but normally done with add-on data logging equipment. The sample rates and the accuracy of the data collected today vary widely. Two-way communications with the utility is practically non-existent. Communications with owners and installers is typically minimal with sample rates that often miss critical data needed to interface with a smart grid. One goal of the SEGIS program was to reverse this trend, while at the same time improving the functionality and intelligence of PV systems.

The "SEGIS Concept Paper" was written as a progressive outline of needs and priorities for initiating a systems level approach to PV systems with "value added" as a primary theme.[5] The SEGIS Concept Paper was used as a guideline to initiate innovative "outside the box" solutions for inroads for high-penetration PV applications. The concepts were aimed at revolutionary (not just evolutionary) advances in technology for interconnections. A continuing requirement for SEGIS was improved component lifetimes (with 20-30 year goals for the complete system), value-added features such as time-of-day priorities for power transfer, and extended mean-time-between-failure for integrated PV systems.

The intermittency of PV power generation becomes a destabilizing factor for utility grids when the amount of intermittent PV power begins to interfere with other generation and protection. Several means to limit the intermittency are possible. Energy storage working in tandem with the PV array can provide equalizing energy when clouds vary the system output. That energy storage may be designed to provide only enough energy to allow other generation to catch up with needs when PV power has suddenly been reduced. Other electronic means such as an adjustable ramp rate for the output power of the PV inverter can be used. Variable volt-ampere reactive (VAr) output from the inverter is another method. The SEGIS work is studying both as commanded functions and as automatic functions for micro-grids. Figure 4 shows a commanded ramp down output for one of the SEGIS developed inverters.

Volt-ampere reactive (VAr) control at the inverter provides a means to control local voltage levels in a very dynamic way. The local voltage can be changed with injection of VArs and that injection can occur via the SEGIS inverters whether or not the sun is shining. The power factor for factories and large motor loads that require VAr support that now comes solely from the utility can also be remotely or automatically adjusted in a similar fashion. A new trend is for utility requirements for PV systems to provide VArs. The first applications of VAr support will be in the mode of scheduled changes as required by the utility.

Next generation SEGIS systems will begin to include energy storage, energy management and interactive communications, which is new to utility-interactive PV systems. Early SEGIS work has determined that communications for more intelligent utility interconnections will likely have to be a combination of linked technologies. SEGIS related communications developments are already being implemented in micro-grid support and with utility-owned microinverter installations on utility poles with direct utility monitoring and control.

The innovative SEGIS work has addressed the complex interconnect standards barriers to progressive "value added" support for the utility grid or for economic benefits of intelligent distributed PV grid-tied systems. Today, the IEEE Std1547 and its addendums still do not allow for deployment of the utility-connected progressive SEGIS developments emerging from SEGIS, but changes are imminent.[6] Most notably operations such as 1) intentional islanding to support stressed grids, 2) low-voltage ride through that may last only a few seconds, but that improves the grid stability, 3) voltampere reactive (VAr) production or alternatively power factor generation by PV inverters that has the potential to be a very dynamic and fine-grained aid in voltage support of stressed grids will be permitted. Low frequency ride-through is a functionality that will be needed in microgrid applications and possibly on smaller independent utility systems.

Most of the SEGIS features are best accomplished with two-way communications between the PV system and the interconnected utility. Some of the features are best accomplished with energy storage in order to be dispatchable and more immune to PV system intermittency. The energy storage or the future will be optimized to obtain the most economically beneficial "value added" features and best economics for each individual installation.

Witness testing on SEGIS Stage 2 prototypes provided valuable insight into the characteristics of each new inverter/controller when functions such as low voltage ride through were exercised. Figure 5 shows the ac voltage and current waveforms for low voltage ride through with a SEGIS inverter/controller. The utility voltage was reduced to zero volts and the legacy anti-islanding function was commanded to change to provide for utility-commanded ride- 


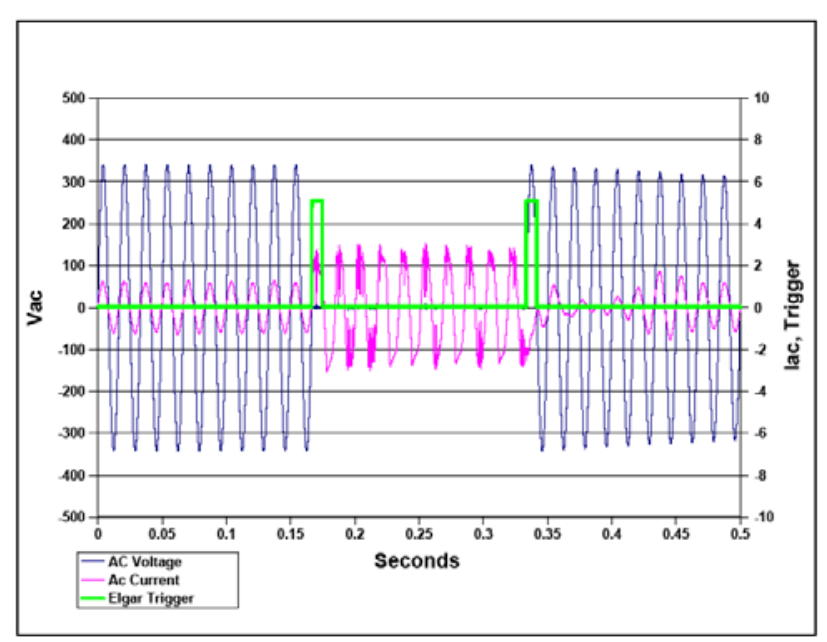

Figure 5. Example of a SEGIS inverter/controller providing utility-commanded ride-thru current.

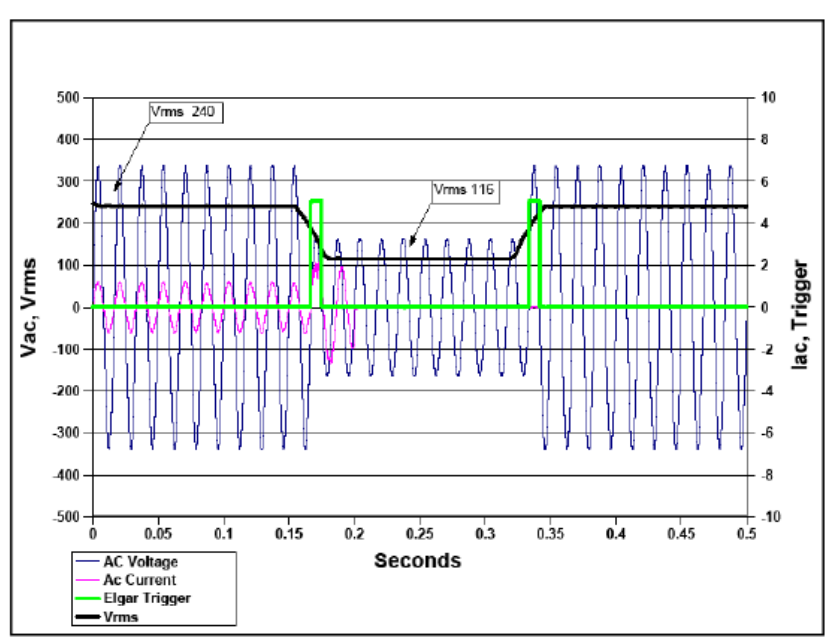

i ure 6. E ample of a SEGIS inverter/controller providin an IEEE1547 re uired islandin shutdo $\mathrm{n}$.

through that assists the recovery of the utility grid rather than further destabilizing by reducing the available power when it is most needed. Ride-through will be most beneficial during periods of voltage sags, but the worst-case zero voltage condition was demonstrated with this test. Figure 6 illustrates the legacy situation where the inverter must disconnect from the grid when voltage drops below IEEE1547 requirements.[6] The disconnect time is dependent upon the severity of the voltage sag.

Other important standards and codes directly affecting SEGIS developments include applicable compatibilities with IEC61850 and the National Electrical Code ${ }^{\circledR}(N E C \circledR) .[7,8]$ The IEC overarching standard 61850 for substation interface and communications includes data modeling, reporting schemes, fast transfer of events for peer-to-peer communication modes, setting groups to control blocks protocol, sampled data transfer, commands and data storage protocols.

As the cost of PV modules and panels decrease, the contribution of inverter/controller and balance-of-system cost and replacement are becoming more significant. Continuation of reducing system costs through improvements and extending the lifetime and reliability are continuing goals. This, along with adding to the value of a PV installation by enabling smart grid functions features will result in benefits beyond that of just displacing the cost of electricity namely the Levelized Cost of Energy (LCOE). New protocols and state-of-the-art communications are being continuing to be pursued in new, smart SEGIS PV system designs.[1,6]

\section{SEGIS CONTRACTORS AND THE DEVELOPMENTS}

The SEGIS contractors completing the “Toward Commercialization” stage are:[9]

1. Petra Solar (South Plainfield, NJ) in collaboration with the University of Central Florida (Orlando, FL) and Fifteen Electric Utilities with service in NJ, PA, OH, DE, MD, DC, FL, TX. This project complements the mission of the Solar Energy Technology Program to achieve a widespread adoption of solar energy. It supports improving reliability and resiliency so that high levels of PV integration can be adapted. Petra has announced and is installing its "Power on a Pole” that is using its early micro-inverter but with some SEGIS features already being utilized.

2. Princeton Power (Princeton, NJ) in collaboration with Princeton Plasma Physics Laboratory (Princeton, NJ) and PEPCO (NJ): This project focuses on lowering manufacturing costs through new components, fully integrated controls for grid interconnect and energy storage, controls for loads, and new inverter/controller/galvanic isolation component designs.

3. PV Powered now merged with Advanced Energy (Bend, OR) with Portland General Electric (Portland, OR), South Dakota State University (Brookings, SD), and Northern Plains Power Technologies (Brookings, SD), Schweitzer Engineering Laboratories (Pullman, WA). This project reinforced the many of the fundamental objectives of the SEGIS 
program to optimize interconnections across the full range of emerging PV-module technologies. New and innovative sensing/communications methods are providing new utility confidence and greater acceptance for PV as a generation source rather than a troublesome negative load.

5. Florida Solar Energy Center/University of Central Florida is collaborating with Satcon Technology Corporation (Boston, MA), SENTECH, Inc. (Bethesda, MD), SunEdison (Beltsville, MD), Northern Plains Power Technologies (Brookings, SD) and Lakeland Electric Utilities (Lakeland, FL): The project focuses on a shared inverter and several technical and communication challenges that have been overcome for higher PV penetration levels in electrical systems. The advances also provide for more effective energy conversion safety, micro-grid controls and system optimizations.

\section{SEGIS ACCOMPLISHMENTS SUMMARY}

A number of unique state-of-the-art component and system configurations have been developed through the hardware and methodologies developed under the SEGIS. Much of the work has resulted in new patent disclosures. This report was limited to describing an overview of accomplishments through the use of waveforms and information collected during witness testing to report on the accomplishments. This paper centered on critical interconnect goals of the SEGIS solicitation.

Functionality and system performance associated with interconnection to an intelligent utility grid is generally divided into ac-side and dc-side discussions. The dc functionality, except as associated with energy storage, was not discussed in detail. The ac output characteristics, commanded functions, operate and shut-down functions were discussed. The ac functionality included three main categories. (1) Legacy functions generally required by UL, IEEE and IEC standards for utility grid interconnection today; (2) Smart functions that include advances that require communications with the utility or owner services; and (3) autonomous functions that are associated with start-up, operate and shut-down, and safety and self-protection.

Hardware and functionality demonstration deployments and conferences are an important part of completing Stage 3 for each contractor. The demonstration conferences are scheduled to take place from September 20 through September 29, 2011. Conference activities will describe, demonstrate and provide impacts of the SEGIS advances. Each conference is in collaboration with partner utilities on real-time, grid-connected and well monitored PV sites.[9]

\section{ACKNOWLEDGEMENT}

Sandia is a multi-program laboratory operated by Sandia Corporation, a Lockheed Martin Company, for the United States Department of Energy's National Nuclear Security Administration under contract DE-AC04-94AL85000. SAND2009-2801P.

\section{REFERENCES}

[1] The Smart Grid: An Introduction; prepared for the U.S. Department of Energy by Litos Strategic Communication under contract No. DE-AC26-04NT41817, Subtask 560.01.04, 2008.

[2] Kroposki, B. et al, "Renewable System Interconnection: Executive Summary", Technical Report NREL/TP-58142292, National Renewable Energy Lab, Golden, CO, Feb 2008. http://www1.eere.energy.gov/solar/pdfs/42292.pdf . [3] April 19 and May 6-7 AII/EMS Workshop Results, http://www2.eere.energy.gov/solar/solar_america/technology_pathway_partnerships_wkshp.html, May 6-7, 2007.

[4] Ton, D., Bower, W., "Solar Energy Grid Integration System (SEGIS) Concept”, Proceedings of the 22nd EU PVSEC, Milan, Italy, Sep 3-7, 2007.

[5] Solar Energy Grid Integration Systems - "SEGIS": Concept Paper, Sandia National Laboratories, Albuquerque, NM, October 2007, http://www.sandia.gov/SAI/files/SEGIS\%20Concept\%20Paper-071025.pdf .

[6] "IEEE Standard 1547.1 for Conformance Tests Procedures for Equipment Interconnecting Distributed Resources with Electric Power Systems,” IEEE, NY, 2009.

[7] IEC 61850, "Communication Networks and Systems in Substations", International Electrotechnical Commission, 3, rue de Varembé,, PO Box 131, CH-1211 Geneva 20, Switzerland.

[8] National Electrical Code, 2008 Edition, NFPA-70 National Fire Protection Association, Battery March, MA, Sep 2007.

[9] SEGIS General Website, http://energy.sandia.gov/?page_id=408 